\title{
UJI EFEK ANTIBAKTERI JAMUR ENDOFIT PADA TUMBUHAN KEMANGI (Ocimum bassilicum L.) PADA BAKTERI UJI Staphylococcus aureus DAN Escherichia coli
}

\author{
Marfincy Silva Walewangko'), Jimmy Posangi' ${ }^{1)}$, Paulina V.Y. Yamlean ${ }^{1)}$ \\ ${ }^{1)}$ Program Studi Farmasi FMIPA UNSRAT Manado, 95115
}

\begin{abstract}
Endophytic microbes are microbes that live in plant tissues. Endophytic fungi can produce various functional compounds in the form of anticancer compounds, antiviral, antibacterial, antifungal and plant growth hormones. Basil (Ocimum Sanctim L.) is the largest species both in fresh form or for the production of essential oils. Ethanol and methanol extracts, from Basil leaves is stated to have antibacterial activity. This study aimed to examine the presence or absence of antibacterial effects of endophytic fungi isolated from the stem and leaves of basil (Ocimum basilicum L.) against Escherichia coli and Staphylococcus aureus. The method used is an experimental laboratory by testing antibacterial activity. From the research carried out four endophytic fungi isolated from the stems and leaves of the Basil (Ocimum basilicum L.) plant. The four endophytic fungi have an antibacterial effect on the two test bacteria. Endophytic fungus from Basil stem 1.2 by $8 \mathrm{~mm}$ which is categorized as medium and extract of Basil Stem 4.1 by $7 \mathrm{~mm}$ which is categorized as medium and Basil Stem $1.1 \mathrm{by} 17 \mathrm{~mm}$ categorized as strong and Basil Leaf 2.1 by $22 \mathrm{~mm}$ categorized as very strong. The conclusion is that endophytic fungi isolated from the Basil (Ocimum bassilicum L.) plant obtained from Lemoh Uner Village have antibacterial activity.
\end{abstract}

Keywords: Antibacterial, Endophytic Fungi, Basil (Ocimum basilicum L.)

\begin{abstract}
ABSTRAK
Mikroba endofit merupakan mikroba yang hidup di dalam jaringan tumbuhan. Jamur endofit dapat menghasilkan berbagai senyawa fungsional berupa senyawa antikanker, antivirus, antibakteri, antifungi serta hormon pertumbuhan tanaman. Kemangi (Ocimum Sanctim L.) merupakan spesies terbesar baik dalam bentuk segar ataupun untuk produksi minyak esensial. Ekstrak etanol, metanol daun Kemangi dinyatakan memiliki aktivitas antibakteri. Penelitian ini bertujuan untuk menguji ada tidaknya efek antibakteri jamur endofit yang diisolasi dari batang dan daun tumbuhan Kemangi (Ocimum basilicum L.) terhadap Escherichia coli dan Staphylococcus aureus. Metode yang digunakan ialah eksperimental laboratorium dengan menguji aktivitas antibakteri. Dari penelitian yang dilakukan diperoleh empat jenis jamur endofit yang diisolasi dari batang dan daun tumbuhan Kemangi (Ocimum basilic um L.). Keempat jamur endofit memiliki efek sebagai antibakteri terhadap kedua bakteri uji. Jamur endofit dari Kemangi batang 1.2 sebesar 8mm yang dikategorikan sedang dan ekstrak Kemangi Batang 4.1 sebesar $7 \mathrm{~mm}$ yang dikategorikan sedang dan Kemangi Batang 1.1 sebesar $17 \mathrm{~mm}$ dikategorikan kuat dan Kemangi Daun 2.1 sebesar 22mm dikategorikan sangat kuat. Kesimpulanya jamur endofit yang diisolasi dari tumbuhan Kemangi (Ocimum bassilicum L.) yang diperoleh dari Desa Lemoh Uner memiliki aktivitas antibakteri.
\end{abstract}

Kata kunci : Antibakteri, Jamur Endofit, Kemangi (Ocimum basilicum L.) 


\section{PENDAHULUAN}

Indonesia dengan luas $4.500 \mathrm{~km}^{2}$ dan terdiri dari lebih dari 17.500 pulau menjadikannya negara kepulauan yang paling besar di dunia. Oleh karena itu, Indonesia juga memiliki keanekaragaman hayati ketiga tertinggi di dunia. Keanekaragaman hayati ini menyebabkan tingginya bioresource dimana tanamantanaman tersebut memiliki bioaktivitas tersendiri sesuai dengan kandungan kimianya diantaranya yaitu Ocimum basilicum L. yang berasal dari genus Ocimum. Genus ini dikenal karena kandungan minyak atsirinya yang berlimpah. Kandungan minyak atsiri yang berlimpah dari berbagai spesies Ocimum seperti Ocimum basilicum L., Ocimum citriodorum, Ocimum basilicum canum Sims. dan spesies Ocimum lainnya dilaporkan memiliki aktivitas antioksidan, antimikroba, insektisida dan aktivitas terapeutik seperti anti-inflamasi, antipiretik, analgesik dan lain-lain (Schulz, 2006).

Mikroba endofit merupakan mikroba yang hidup di dalam jaringan tumbuhan dan mampu membentuk koloni dalam jaringan tumbuhan tanpa memberikan efek negatif pada inangnya. Mikroba endofit dapat berupa bakteri, jamur atau mikroba lainnya, tetapi saat ini yang lebih banyak dieksplorasi ialah jamur endofit. Isolat-isolat jamur endofit memiliki daya antibakteri yang poten dengan spektrum luas (Rukmana, 2016).

Jamur endofit dapat menghasilkan berbagai senyawa fungsional berupa senyawa antikanker, antivirus, antibakteri, antifungi serta hormon pertumbuhan tanaman. jamur endofit banyak menghasilkan senyawa bioaktif yang digunakan untuk meningkatkan ketahanan inang dari serangan patogen. Jamur endofit menginfeksi tumbuhan yang sehat pada jaringan tertentu dan mampu menghasilkan mikotoksin, enzim serta antibiotik (Noverita, 2009).

Staphylococcus aureus sering ditemukan sebagai bakteri flora normal pada kulit dan selaput lendir pada manusia, namun kuman ini juga dapat menjadi penyebab infeksi pada manusia maupun hewan. Staphylococcus aureus dapat menginfeksi jaringan atau alat tubuh lain yang menyebabkan timbulnya penyakit dengan tanda-tanda yang khas seperti nekrosis, peradangan dan pembentukan abses (Angelina, 2015).

Bakteri yang merupakan bagian dari mikroflora yang secara normal ada dalam saluran pencernaan manusia dan hewan berdarah panas yaitu Escherichia coli. Escherichia coli termasuk ke dalam bakteri heterotrof yang memperoleh makanan berupa zat oganik dari lingkungannya karena tidak dapat menyusun sendiri zat organik yang dibutuhkannya (Angelina, 2015).

Zona hambatan terhadap pertumbuhan bakteri akan semakin besar seiring dengan peningkatan konsentrasi yang ditambahkan.

Adanya perbedaan zona hambatan pada masingmasing konsentrasi disebabkan karena perbedaan besarnya zat aktif yang terkandung pada konsentrasi tersebut. Semakin besar suatu konsentrasi, semakin besar pula komponen zat aktif yang terkandung di dalamnya sehingga zona 
hambatan yang terbentuk juga berbeda (Brooks, 2005).

\section{METODOLOGI PENELITIAN}

\section{Waktu dan Tempat Penelitian}

Penelitian ini telah dilaksanakan pada bulan Maret sampai Juni 2019 di Laboratorium Biologi Molekuler dan Farmasetika Laut Fakultas Perikanan dan Ilmu Kelautan Universitas Sam Ratulangi Manado serta Laboratorium Lanjutan Devisi Mikrobiologi Program Studi Farmasi Fakultas Matematika dan Ilmu Pengetahuan Alam Universitas Sam Ratulangi.

\section{Bentuk Penelitian}

Metode yang digunakan dalam penelitian ini yaitu metode eksperimental. Dan untuk pengukuran aktivitas antibakteri digunakan metode difusi cakram.

\section{Alat dan Bahan}

a. Alat

Alat-alat yang digunakan yaitu cawan petri, erlenmeyer, autoklaf, gunting, pinset, kertas label, lakban, keranjang, kompor, mikrotip, sedotan, lampu spritus, kawat ose, laminar air flow, oven, evaporator, labu evaporator.

b. Bahan

Bahan-bahan yang digunakan yaitu batang, dan daun tumbuhan Kemangi, potato dextrose agar (PDA), medium nutrient agar (NA), alkohol 95\%, alkohol 75\% aquades, kapsul kloramfenikol 250 mg, beras, kertas cakram.

\section{Prosedur Penelitian Preparasi Sampel}

Dan untuk pengambilan sampel, sampel Kemangi diambil di Desa Lemoh
Uner, Jaga III Kec. Tombariri Timur Kab. Minahasa pada bulan Maret 2019. Kemudian tanaman Kemangi yang sudah diambil dibersihkan. Daun dan batang Kemangi yang dibersihkan kemudian dipotong menggunakan gunting dan dipotong menjadi 4 bagian kecil. Sebelum ditanamkan kedalam media PDA+AB rendam terlebih dahulu alat-alat dan sampel yang akan diguanakan dalam larutan alkohol 95\% selama 1 menit untuk menghindari kontaminasi bakteri. Potongan sampel tersebut kemudian diangkat menggunakan pingset yang sudah direndam didalam larutan alkohol terlebih dahulu dan sudah dibakar selama beberapa menit dengan menggunakan lampu spritus (Yohanis, 2017).

\section{Sterilisasi dan Pembuatan Media Sterilisasi Alat}

Alat-alat yang digunakan dalam
penelitian aktivitas antimikroba ini
disterilkan terlebih dahulu dengan
menggunakan autoklaf pada suhu $121{ }^{\circ} \mathrm{C}$
selama 15 menit, pinset dibakar dengan
pembakaran di atas api langsung dan media
disterilkan di autoklaf pada suhu $121{ }^{\circ} \mathrm{C}$
selama 15 menit (Ortez, 2005).

\section{Pembuatan Media PDA dan PDA+AB Pembuatan Media PDA}

Media PDA yang dibuat sesuai kebutuhan. Pada saat pembuatan 15 media, PDA ditimbang sebanyak 11,7 g dan ditambahkan NA sebanyak 3,6 g dan dilarutkan kedalam $300 \mathrm{ml}$ aquades. 1 media diperlukan setidaknya 20mL. Kemudian dipanaskan didalam Erlenmeyer selama beberapa menit sehingga kedua bahan tersebut menyatu. Kemudian PDA yg sudah 
dipanaskan tadi dimasukan kedalam autoklaf untuk disterilisasi. Selama proses sterilisasi autoklaf harus terus dipantau supaya suhunya tetap stabil agar tidak merusak proses sterilisasi tersebut. Setelah disterilisasi PDA tersebut kemudian dituangkan kedalam cawan petri yang sudah disterilisasi terlebih dahulu. Proses penuangan PDA dilakukan di dalam alat laminar airflow agar tetap steril. Selama proses penuangan PDA tangan harus disterilkan menggunakan alkohol. Setelah dituang, cawan petri harus langsung ditutup menggunakan lakban dengann melingkari seluruh pinggiran luar cawan petri agar tidak terkontaminasi oleh organisme dari luar (Michelle, 2014).

\section{Pembuatan Media PDA+AB}

Proses pembuatan media PDA+AB juga sama seperti pembuatan media sebelumnya hanya saja disini PDA ditambahkan dengan antibiotik kloramfenikol sebanyak $150 \mathrm{~mL}$. Tujuan penambahan antibiotik pada media PDA yaitu agar mencegah terjadinya pertumbuhan bakteri pada media. Pembuatan media PDA+AB ada 4 media. Diambil PDA sebanyak 3.9 g, NA seabanyak 1,2 g dan aquades sebanyak 100 mL. Kemudian panaskan seperti cara pembuatan PDA sebelumnya (Michelle, 2014).

\section{Pembuatan Media PDA+AB}

Proses pembuatan media $\mathrm{PDA}+\mathrm{AB}$ juga sama seperti pembuatan media sebelumnya hanya saja disini PDA ditambahkan dengan antibiotik kloramfenikol sebanyak $150 \mathrm{~mL}$. Tujuan penambahan antibiotik pada media PDA yaitu agar mencegah terjadinya pertumbuhan bakteri pada media. Pembuatan media PDA+AB ada 4 media. Diambil PDA sebanyak 3.9 g, NA seabanyak 1,2 g dan aquades sebanyak 100 mL. Kemudian panaskan seperti cara pembuatan PDA sebelumnya (Michelle, 2014).

\section{Isolasi Jamur Pada Media PDA+AB}

Setelah sampel di preparasi, kemudian sampel ditanam pada media Potato Dextrose Agar (PDA)+AB di dalam cawan petri. Cawan petri yang berisi daun dan Kemangi tersebut ditutup menggunakan lakban agar tidak terjadi kontaminasi oraganisme lain dari luar, kemudian disimpan pada suhu ruangan selama 3 x 24 jam untuk menumbuhkan jamur. Pada hari ke-1 tidak terlihat pertumbuhan dari jamur di sekitar batang dan daun Kemangi didalam media. Kemudian pada hari ke tiga sudah mulai tumbuh jamur pada batang dan daun Kemangi. (Michelle, 2014).

\section{Pemurnian Jamur Endofit}

Pada hari ketiga setelah penanaman sampel terlihat adanya jamur yang tumbuh dipermukaan media PDA+AB. Jamur yang sudah tumbuh diambil koloni yang terdapat pada permukaan media dengan kawat ose dan dipindahkan ke media PDA yang lain untuk ditumbuhkan kembali. Ini bertujuan untuk mendapatkan 1 jenis jamur endofit yang murni. Simpan pada suhu ruangan selama $2 \quad \mathrm{X} \quad 24$ jam. Jamur yang dipindahakan yaitu berasal dari media yang ditanamkan sampel daun ada dua media dan sampel batang ada dua media. Jadi total 
pemindahan jamur ada empat media (Michelle, 2014).

\section{Pembuatan Media Kulturnasi}

Pembuatan media ini menggunakan beras yang ditimbang sebanyak $40 \mathrm{~g}$ dan aquades sebanyak $50 \mathrm{~mL}$. Dimasukkan kedalam Erlenmeyer untuk kemudian disterilisasikan kedalam autoklaf. Ini bertujuan juga agar beras tersebut bisa masak. Sebelumnya Erlenmeyer harus ditutup terlebih dahulu menggunakan kain kasa yang telah berbentuk bulat dan kemudian dibungkus lagi menggunakan kertas alumunium foil. Autoklaf dilakukan selama 20 menit pada suhu $120^{\circ} \mathrm{C}$ dengan tekanan 1atmosfer. Setelah itu didinginkan untuk dilakukan penanaman jamur pada media (Yohanes, 2017).

\section{Pemindahan Miselia pada Media Kulturnasi}

Miselia yang sudah tumbuh diambil sebagian dari permukaan agar dengan cara dipotong memanjang dan dipotong lagi menjadi bagian-bagian kecil berbentuk segi empat. Kemudian dipindahkan ke media beras yang sudah dimasak tadi. Sebelumnya alat yang akan digunakan untuk memotong harus disterilisasikan terlebih dahulu dengan dicelupkan kedalam alkohol. Ujung dari Erlenmeyer yang berisikan nasi tersebut juga harus dipanaskan atau dibakar pada lampu spritus beberapa detik kemudian baru bisa dibuka dan dimasukan jamur kedalam erlenmeyer. Ini bertujuan untuk membunuh oragnisme yang terdapat pada ujung Erlenmeyer dan kasa. Pada saat pemindahan juga dipastikan tangan sudah disterilkan menggunakan alkohol terlebih dahulu. Erlenmeyer yang sudah dimasukkan jamur ditutup kembali. Kasa dan ujung erlenmeyer dibakar secara bersamaan sebelum ditutup kembali dan kemudian dibungkus menggunakan perban agar tidak terjadi kontaminasi. Jamur didiamkan selama 7-10 hari untuk dilihat pertumbuhannnya (Yohanis, 2017).

\section{Kultivasi dan Pemberian Pelarut Etil Asetat}

Setelah didamkan selama 3-5 hari jamur dalam media kulturnasi, dicek kembali apakah jamur yang sudah tumbuh mencapai bagian dasar nasi dalam labu erlenmeyer. Jika sudah menutupi semua nasi, diberikan pelarut etil asetat sebanyak $200 \mathrm{~mL}$ sampai nasi terendam. Kemudian menggunakan kawat ose jamur yang sudah tumbuh dan menutupi semua permukaan nasi diaduk-aduk hingga pelarut etil asetat dapat menembus semua permukaan nasi. Pemberian pelarut etil asetat kedalam media kulturnasi ini bertujuan agar supaya pelarut bisa masuk kedalam sel sehingga diharapkan senyawa-senyawa yang ada di dalam media tersebut bisa keluar. Setalah berikan pelarut, maka media harus di aduk-aduk selama 1x24 jam menggunakan alat shaker agar media benar-benar terlarut dan senyawasenyawa bisa keluar (Yohanes, 2017).

\section{Proses Evaporasi}

Setelah 1x24 jam di aduk-aduk menggunakan alat shaker, ekstrak yang ada dalam labu erlenmeyer dipindahkan kedalam labu evaporator untuk dilakukan proses evaporasi pada suhu $40^{\circ} \mathrm{C}$. Jika ekstrak mulai habis atau mengering ditambahkan sedikit alkohol 95\% untuk membantu pengenceran ekstrak yang masih tersisa, lalu dilakukan kembali proses evaporasi untuk mendapatkan kekentalan dari ekstrak tersebut. Jika sudah kental, ekstrak 
dipindahkan kedalam botol kecil untuk dikeringkan (dengan cara diuapkan) untuk selanjutnya akan diuji antibakterinya (Michelle, 2014).

\section{Pengukuran Aktivitas Antibakteri}

Metode yang digunakan dalam penelitian ini yaitu metode difusi cakram. Pada pengujian aktivitas antimikroba ini, cakram yang digunakan berukuran $6 \mathrm{~mm}$ dengan daya serap $50 \mu \mathrm{L}$ tiap cakram. Bakteri S. aureus dan E. coli masing-masing diambil menggunakan kawat ose dilarutkn dalam $5 \mathrm{~mL} \mathrm{NaCl}$ kemudian dikocok-kocok hingga homogen dan kemudian menggunakan mikropipet $0,4 \mathrm{~mL}$ suspensi bakteri diambil dan dimasukkan kedalam media NA, kemudian dikocok hingga tercampur. Media NA yang sudah diberikan suspensi bakteri dituangkan ke dalam cawan petri dan tunggu sampai media agar mengeras. Setelah agar mengeras, kertas cakram yang telah ditotolkan sampel ekstrak batang dan daun tumbuhan Kemangi, kontrol positif dan kontrol negatif diletakkan ke dalam cawan petri dengan menggunakan pinset. Selanjutnya, cawan petri diberi label dan diinkubasi dalam inkubator pada suhu $37^{\circ} \mathrm{C}$ selama 1 x 24 Jam (Ortez, 2005).

\section{Pengamatan dan Pengukuran Diameter Zona Hambat}

Pengamatan dilakukan setelah 24 jam masa inkubasi. Daerah pada sekitaran cakram menunjukkan kepekaan ekstrak terhadap bakteri yang digunakan sebagai bahan uji yang dinyatakan dengan diameter zona bening. Diameter zona bening diukur menggunakkan jangka sorong. Kemudian zona bening yang diukur (Davis, 1971).

\section{HASIL DAN PEMBAHASAN}

Isolat Jamur Endofit Daun dan Batang Tumbuhan Kemangi

Pembiakan jamur endofit yang berasal dari daun dan batang tumbuhan Kemangi yang diambil dari Desa Lemoh Uner Jaga III Kec. Tombariri Timur Kab. Minahasa menghasilkan empat jenis jamur secara makroskopik. Tiga jamur dari Kemangi batang, satu jamur dari Kemangi daun. Secara makroskopik pembiakan semua jamur memiliki karakteristik yang sama yaitu miselia berwarna pitih (Strobel, 2004). Dapat dilihat pada Gambar 1.

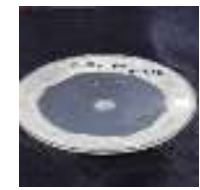

(A)

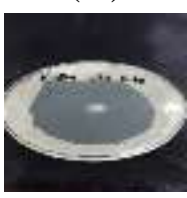

(D)

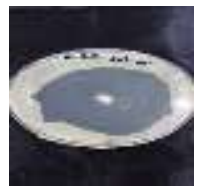

(B)

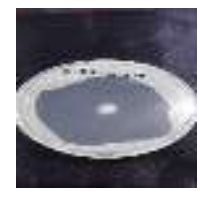

(C)

\section{Gambar 1. Biakan Jamur Endofit.}

Keterangan :

(A). Jamur endofit pembiakan dari sampel Kemangi Batang (K.B1)

(B). Jamur endofit pembiakan dari sampel Kemangi Batang (K.B 2)

(C). Jamur endofit pembiakan dari sampel Kemangi Batang (K.B 3)

(D). Jamur endofit pembiakan dari sampel Kemangi Daun (K.D 4)

\section{Aktivitas Antibakteri Isolat Jamur Endofit}

Pada penelitian ini dilakukan sebanyak empat sampel untuk kedua jenis bakteri uji. Hasil pengujian efek antibakteri jamur endofit daun, dan batang tumbuhan Kemangi (Ocimum bassilicum L.) 
menghasilkan adanya aktivitas dan daya hambat yang di tandai dengan adanya zona bening terdapat disekeliling cakram yang masing-masing berbeda berukuran, dengan adanya zona bening menunjukkan adanya kepekaan terhadap ekstrak Kemangi. Pengamatan ini dilakukan setelah di inkubasi selama $1 \times 24$ jaM pada suhu $37^{\circ} \mathrm{C}$. Pada Tabel 1 menunjukkan hasil rata-rata uji aktivitas antibakteri dari ekstrak Kemangi batang dan daun.

\begin{tabular}{|c|c|c|c|c|c|}
\hline Tabel & $\begin{array}{l}\text { 1.Has } \\
\text { Antiba } \\
\text { batang } \\
\text { bakter } \\
\text { dan } E s\end{array}$ & $\begin{array}{l}\text { ri } \\
\text { dan } \\
\text { uji } S t \\
\text { herict }\end{array}$ & $\begin{array}{l}\text { a-rata } \\
\text { ekstrak } \\
\text { daun } \\
\text { phyloco } \\
\text { a coli }\end{array}$ & \multicolumn{2}{|c|}{$\begin{array}{r}\text { Aktivitas } \\
\text { Kemangi } \\
\text { terhadap } \\
\text { ccus aureus }\end{array}$} \\
\hline \multirow{3}{*}{ Sampel } & \multirow{2}{*}{\multicolumn{3}{|c|}{ Escherichia coli }} & \multirow{3}{*}{$\mathbf{K}(+)$} & \multirow{3}{*}{$\mathbf{K}(-)$} \\
\hline & & & & & \\
\hline & $\begin{array}{c}\mathrm{U} 1 \\
(\mathrm{~mm})\end{array}$ & $\begin{array}{c}\mathrm{U} 2 \\
(\mathrm{~mm})\end{array}$ & $\begin{array}{c}\mathrm{U} 3 \\
(\mathrm{~mm})\end{array}$ & & \\
\hline K.B 1.1 & 17 & 16 & 18 & - & - \\
\hline K.B 1.2 & - & - & - & 6,5 & - \\
\hline K.B 2.1 & 24 & 25 & 22 & 6,5 & - \\
\hline K.D 4.1 & 7 & 7 & 6,5 & - & - \\
\hline \multirow{3}{*}{ Sampel } & \multirow{2}{*}{\multicolumn{3}{|c|}{ Staphylococcus aureus }} & & \\
\hline & & & & $\mathbf{K}(+)$ & $\mathbf{K}(-)$ \\
\hline & $\begin{array}{c}\mathrm{U} 1 \\
(\mathrm{~mm})\end{array}$ & $\begin{array}{c}\mathrm{U} 2 \\
(\mathrm{~mm})\end{array}$ & $\begin{array}{c}\text { U3 } \\
(\mathrm{mm})\end{array}$ & & \\
\hline K.B 1.1 & 15 & 14 & 17 & - & - \\
\hline K.B 1.2 & 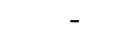 & 8 & - & - & - \\
\hline K.B 2.1 & 21 & 22 & 20 & - & - \\
\hline K.D 4.1 & - & - & - & - & - \\
\hline
\end{tabular}

Keterangan :

K.B 1.1 : Kemangi Batang 1.1

K.B 1.2 : Kemangi Batang 1.2

K.B 2.1 : Kemangi Batang 2.1

K.D 4.1 : Kemangi Daun 4.1

U1 : Ulangan 1

$\mathrm{K}(+)$ : Kontrol Positif

U2 : Ulangan 2

K (-) : Kontrol Negatif

U3 : Ulangan 3
Pada pengujian ini digunakan kontrol positif dan negatif sebagai pembanding. kontrol positif yang digunakan dalam penelitian ini yaitu Kloramfenikol, digunakan kloramfenikol dikarenakan Kloramfenikol memiliki spektrum yang luas. Penggunaan kontrol positif berfungsi sebagai kontrol dari zat uji, dengan membandingkan diameter daerah hambat yang terbentuk (Dwijendra, 2014). Kontrol negatif yaitu akuades, kontrol negatif digunakan untuk mengetahui ada atau tidaknya pengaruh terhadap pertumbuhan mikroba uji. Kontrol negatif digunakan untuk mengetahui ada atau tidaknya pengaruh terhadap pertumbuhan bakteri uji, sehingga dapat diketahui bahwa aktivitas yang ditunjukan oleh ekstrak ialah zat yang terkandung dalam sampel bukan berasal dari pelarut yang digunakan. Diperoleh zona hambat keseluruhan dari kontrol positif Kloramfenikol yaitu sebesar 6,5 mm dibandingkan dengan kontrol negatif yang tidak terdapat zona bening dan aktivitas antibakteri (Mujipradhana, 2018).

Pada penelitian ini ekstrak dari tumbuhan Kemangi merupakan ekstrak yang efektif dalam menghambat pertumbuhan bakteri gram positif Staphylococcus aureus bakteri gram negatif Escherichia coli. Pada pengujian aktivitas antibakteri dari sampel Kemangi, penggolangan kekuatan daya antibakteri digolongkan menurut pedoman Davis and Stout (1971) yang ditunjukkan pada Tabel 2. 


\begin{tabular}{|c|c|c|}
\hline Tabel & $\begin{array}{l}\text { 2.Kategori } \\
\text { Antibakteri } \\
\text { Pedoman D }\end{array}$ & $\begin{array}{l}\text { Kekuatan } \\
\text { Berdasa } \\
\text { vis and Stout (19 }\end{array}$ \\
\hline & $\begin{array}{l}\text { iameter zona } \\
\text { bening }(\mathrm{mm})\end{array}$ & Kategori \\
\hline & $\geq 20$ & Sangat Kuat \\
\hline & $10-20$ & Kuat \\
\hline & $5-10$ & Sedang \\
\hline & $\leq 5$ & Lemah \\
\hline
\end{tabular}

Ekstrak K.B 1.1 menunjukkan bahwa zona bening yang terbentuk pada Escherichia coli tergolong kuat dimana pada ulangan 1 yaitu $(17 \mathrm{~mm})$, ulangan 2 yaitu (16 mm), serta ulangan 3 yaitu $(18 \mathrm{~mm})$ dan pada Staphylococcus aureus juga tergolong kuat dimana ulangan 1 yaitu $(15 \mathrm{~mm})$, ulangan 2 (14 mm), ulangan $3(17 \mathrm{~mm})$. Hal ini menunjukkan bahwa ekstrak batang Kemangi memiliki spektrum kerja yang luas dalam menghambat aktivitas antibakteri dengan bakteri Staphylococcus aureus, Escherichia coli. Hal ini juga dipengaruhi oleh kandungan kimia teringgi Kemangi terdapat pada batang Kemangi (Kicel, 2005)

Ekstrak K.B 1.2 ulangan 1, ulangan 2 dan ulangan 3 menunjukkan bahwa tidak terdapat zona bening yang terbentuk pada Escherichia coli yaitu $(0 \mathrm{~mm})$ dan pada Staphylococcus aureus juga hanya pada ulangan 2 yang terdapat zona bening $(8 \mathrm{~mm})$ selain itu tidak terdpat zona bening yaitu $(0$ $\mathrm{mm})$. Hal ini menunjukkan bahwa ekstrak K.B 1.2 memiliki spektrum kerja yang sempit dalam menghambat aktivitas antibakteri dengan bakteri Staphylococcus aureus, Escherichia coli.

Ekstrak K.B 2.1 menunjukkan bahwa zona bening yang terbentuk pada Escherichia coli tergolong sangat kuat yaitu Ulangan 1 (24 mm), Ulangan $2(25 \mathrm{~mm})$,
Ulangan 3 (22 $\mathrm{mm})$ dan pada Staphylococcus aureus juga tergolong sangat kuat yaitu Ulangan 1 (21 $\mathrm{mm})$, Ulangan 2 (22 mm), Ulangan $3(20 \mathrm{~mm})$. Hal ini menunjukkan bahwa ekstrak K.B 2.1 memiliki spektrum kerja yang luas dalam menghambat aktivitas antibakteri dengan bakteri Staphylococcus aureus, dan Escherichia coli. Hal ini juga dipengaruhi oleh kandungan kimia teringgi Kemangi terdapat pada batang Kemangi (Kicel, 2005)

Ekstrak K.D 4.1 menunjukkan bahwa zona bening yang terbentuk pada Escherichia coli yaitu Ulangan 1 (7 mm), Ulangan 2 (7 mm), Ulangan $3(6,5 \mathrm{~mm})$ dan pada Staphylococcus aureus tidak terdpat zona bening yaitu Ulangan $1(0 \mathrm{~mm})$, Ulangan 2 (0 mm), Ulangan $3(0 \mathrm{~mm})$. Hal ini menunjukkan bahwa ekstrak K.D 4.1 memiliki spektrum kerja yang sempit dalam menghambat aktivitas antibakteri dengan bakteri Staphylococcus aureus dan Escherichia coli.

Hasil yang diperoleh menunjukkan bahwa ekstrak K.B 1.2 dan K.D 4.1 menghasilkan zona bening berdiameter sedang dan lemah untuk mengambat pertumbuhan bakteri uji Staphylococcus aureus dan Escherichia coli. Ekstrak K.B 1.1 dan ekstrak K.B 2.1 menghasilkan zona bening berdiameter sangat kuat dan mampu mengambat pertumbuhan bakteri uji Staphylococcus aureus dan Escherichia coli. Berdasarkan penelitian sebelumnya menunjukkan ekstrak Kemangi daun berdiameter sangat kuat karena dipengaruhi oleh kandungan kimia teringgi Kemangi terdapat pada daun Kemangi (Kicel, 2005) 


\section{KESIMPULAN}

Berdasarkan hasil penelitian yang telah dilakukan dapat disimpulkan bahwa jamur endofit yang diisolasi dari tumbuhan Kemangi (Ocimum bassilicum L.) dari Desa Lemoh Uner memiliki aktivitas antibakteri. Ekstrak Kemangi batang 1.2 sebesar $8 \mathrm{~mm}$ yang dikategorikan sedang dan ekstrak Kemangi Batang 4.1 sebesar $7 \mathrm{~mm}$ yang dikategorikan sedang dihasilkan pada bakteri Staphylococcus aureus dan Escherichia. Ekstrak Kemangi Batang 1.1 sebesar $17 \mathrm{~mm}$ dikategorikan kuat dan Kemangi Daun 2.1 sebesar $22 \mathrm{~mm}$ dikategorikan sangat kuat.

\section{SARAN}

Dari hasil dan pembahasan aktivitas antibakteri ekstrak Kemangi maka dapat diberikan saran yaitu perlu dilakukan pengujian efek antibakteri menggunakan ekstrak Kemangi akar dan terhadap bakteri jenis lainnya, serta melakukan pengujian efek samping, efek toksik, senyawa aktif dan identifikasi dari jamur endofit yang diisolasi dari tumbuhan Kemangi (Ocimum bassilicum L.).

\section{DAFTAR PUSTAKA}

Angelina, Maria, Masnur Turnip, and Siti Khotimah. Uji Aktivitas Antibakteri Ekstrak Etanol Daun Kemangi (Ocimum sanctum L.) Terhadap Pertumbuhan Bakteri Escherichia coli dan Staphylococcus aureus. Protobiont 4.1 (2015).

Brooks, G.F., Butel, J.S., Morse, S.A., 2005. Mikrobiologi Kedokteran Jawetz, Melnick, \& Adelberg ed.23. EGC, Jakarta
Davis, W. W., T.R. Stout. 1971. Disc plate method of microbiological assay. Journal of microbiology. 22: 659665.

Kicel. Uji Aktivitas Antibakteri Ekstrak Daun Kemangi (Ocimum sanctum L.) Terhadap Pertumbuhan Bakteri Escherichia coli dan Staphylococcus aureus. Protobiont 4.1 (2005).

Michelle Sumampouw, et al.2014. Uji Efek Antibakteri Jamur Endofit Akar Bakau Rhizopora Stylosa Terhadap Bakteri Staphylococcus Aureus Dan Escherichia Coli. Jurnal e-Biomedik. Vol(2) No (1).

Noverita, D. Fitria dan E. Sinaga. 2009. Isolasi dan uji aktivitas antibakteri jamur endofit dari daun rimpang Zingiber ottensiin Val. Jurnal Farmasi Indonesia, 4(4): 171-176.

Ortez, J. H. 2005. Disk Diffusion testing in manual of antimicrobial susceptibility testing. Marie B. Coyle (Coord. Ed). American society for Microbiology, America.

Rukmana rahmat $h$, Yudirahman Herdi $h$. 2016. Kemangi dan selasih. Liliy Publisher. Jogyakarta.

Schulz B, Boyle C. 2006. What are Endophytes. Soil Biology. ;9:1.

Yohanis Nawea, et al. 2017. Uji Antibakteri Jamur Endofit Dari Tumbuhan Mangrove Soneratia alba Yang Tumbuh Di Perairan Pantai Tanahwangko. Jurnal Pesisir dan Laut Tropis. Vol (1) No (1).

Schlagel,G.H. 1993.General Microbiologi seventh edition. Cambrige University Press. 